Research Article

\title{
Difference of Maternal Serum Interleukin-8 in Preterm Labor and Full Term Labor
}

\section{Perbedaan Kadar Interleukin-8 Maternal pada Persalinan Preterm dan Persalinan Aterm}

\author{
Komang W Budiartha, Tjokorda G A Suwardewa \\ Department of Obstetrics and Gynecology \\ Faculty of Medicine University of Udayana/ \\ RSUP Sanglah Hospital \\ Denpasar
}

\begin{abstract}
Objective: To determine the difference of maternal interleukin-8 (IL-8) in preterm labor and full term labor.

Method: This is a cross sectional study with 68 samples, 29 subjects with preterm labor and 39 subjects with full term labor. IL-8 concentration was obtained from blood samples of the subjects, which were examined at Prodia Laboratory Denpasar. Data was analyzed using t-test for independent samples with $=0.05$.

Result: The mean IL-8 level for the preterm labor group was $23.5610 .69 \mathrm{pg} / \mathrm{ml}$ and $12.195 .79 \mathrm{pg} / \mathrm{ml}$ for the full term labor group. Statistical analysis using independent samples t-test showed that the average IL-8 level of both groups were significantly different $(\mathrm{p}=0.001)$.

Conclusion: We concluded from this study that serum IL-8 concentration in women who had preterm labor is significantly higher in comparison to women who had full term labor.

[Indones J Obstet Gynecol 2014; 4: 185-187]

Keywords: full term labor, interleukin-8, preterm labor
\end{abstract}

\begin{abstract}
Abstrak
Tujuan: Untuk mengetahui perbedaan kadar interleukin-8 (IL-8) pada persalinan preterm dan persalinan aterm.

Metode: Penelitian ini menggunakan desain potong lintang dengan 68 sampel, di mana 29 sampel dengan persalinan preterm dan 39 sampel dengan persalinan aterm. Kadar IL-8 diperiksa dari sampel darah subjek yang diperiksakan di Laboratorium Prodia Denpasar. Uji statistik yang digunakan adalah t-test untuk sampel independen dengan tingkat kemaknaan $=0,05$.

Hasil: Rerata kadar IL-8 pada kelompok persalinan preterm adalah 23,56 10,69 pg/ml, sedangkan pada kelompok persalinan aterm adalah $12,195,79 \mathrm{pg} / \mathrm{ml}$. Analisis statistik dengan t-test untuk sampel independen didapatkan nilai $p=0,001$ menunjukkan bahwa rerata kadar IL-8 pada kedua kelompok memiliki perbedaan yang bermakna.

Kesimpulan: Berdasarkan hasil penelitian ini didapatkan bahwa kadar IL-8 serum pada perempuan dengan persalinan preterm secara bermakna lebih tinggi daripada perempuan persalinan aterm.

[Maj Obstet Ginekol Indones 2014; 4: 185-187]

Kata kunci: interleukin-8, persalinan aterm, persalinan preterm
\end{abstract}

Correspondence: Komang W Budiartha, Department of Obstetrics and Gynecology, Faculty of Medicine University of Udayana, Denpasar, Bali. Phone: 081246382638, email: boedi_artha@yahoo.com

\section{INTRODUCTION}

Up to this day, preterm labor is still a major problem, especially in obstetrics and perinatology. Both in developed and modern countries, the leading cause of neonatal morbidity and mortality is preterm labor, responsible for approximately $75 \%$ of neonatal death. Worldwide, $70 \%$ of preterm labor leads to perinatal death and almost half of them leads to long term neurological abnormality. ${ }^{1}$

Patients with clinical symptoms of preterm labor show an increase of various cytokines in the maternal serum, leading us to assume that cytokines play an important role in the initiation of preterm labor. One of the inflammatory cytokine found in serum is interleukin-8 (IL-8). Several studies have shown that the increase of maternal serum IL-8 is related to initiation of preterm labor, eventhough studies are still contradictive. ${ }^{2,3}$ IL-8 is a chemotactic factor involved in maturation of the cervix during the onset of labor. The main function of IL-8 is induction of chemotactic process on neutrophil as the target cell. IL-8 concentration increases in the cervix during the onset of labor and is involved in the process of tissue transformation during the cervical maturation process. ${ }^{4}$

In full term labor, the cervical maturation process happens in the second phase of labor (active phase). This process is marked by transformation of cervical structure and stromal invasion by inflammatory cells. It triggers a hypothesis that the cervical maturation process is an inflammatory 
process where IL-8 acts as a chemoattractant, inserting inflammatory cells into the cervix. ${ }^{5}$ Previous studies have demonstrated an increase of IL8 level after onset of labor in full term labor. ${ }^{6}$ Compared to full term labor, IL-8 secretion is higher in preterm labor. ${ }^{7}$ This study aims to determine the difference of maternal serum IL-8 in preterm and full term labor.

\section{METHODS}

This research utilizes a cross sectional method. Our sample were recruited using consecutive sampling from the reachable population. The subjects were pregnant women around 28 to 37 weeks (preterm) and above 37 weeks (full term) who presented to the outpatient clinic and delivery room at Sanglah Hospital and were diagnosed with preterm or full term labor along with fulfilling the inclusion criteria.

The inclusion criteria were singleton pregnancy, 28 to 37 weeks of pregnancy (preterm) and above 37 weeks of pregnancy (full term), and volunteered to participate in the research. Meanwhile, the exclusion criteria were presence of congenital abnormalities or systemic diseases, history of preterm labor in previous pregnancies or has been treated for threatened preterm delivery in the current pregnancy, polyhidramnion, multiple pregnancy, history of medical treatments with antibiotics, tocolytics or anti-inflammatories within the past week.

This reaserch was conducted from December 2011 until May 2012. Our sample was divided into two groups: 29 women with preterm labor and 39 women with full term labor We collected blood samples from the subjects and checked for serum IL-8 at Prodia Laboratory Denpasar. Data was processed using SPSS for Windows version 17.0.

\section{RESULTS}

In this cross sectional study the diferrence of maternal age and parity between both groups was tested using independent t-test. The result is shown in Table 1.
Table 1. Mean Difference of Maternal Age and Parity in Preterm and Full Term Labor.

\begin{tabular}{lccc}
\hline \multicolumn{1}{c}{ Variables } & $\begin{array}{c}\text { Preterm } \\
\text { labor } \\
(\mathbf{n = 2 9 )}\end{array}$ & $\begin{array}{c}\text { Fullterm } \\
\text { labor } \\
(\mathbf{n = 3 9 )}\end{array}$ & $\mathbf{p}$ \\
\hline $\begin{array}{l}\text { Maternal age } \\
\text { (years) }\end{array}$ & 27.104 .92 & 27.595 .66 & 0.300 \\
Parity & 0.971 .09 & 1.211 .13 & 0.308 \\
\hline \hline
\end{tabular}

Table 1 shows that there was no significant diference in terms of maternal age and parity ( $p>0.05$ ). Therefore, these variables will not affect the result. To determine the mean difference in serum IL-8 level, we performed independent t-test. The result is shown in Table 2 .

Table 2. Mean Difference of IL-8 Level in Preterm and Full Term Labor.

\begin{tabular}{lllcl}
\hline \hline \multirow{2}{*}{ Group } & N & \multicolumn{2}{c}{ IL-8 Level $(\mathbf{p g} / \mathbf{m l})$} & \multirow{2}{*}{$\mathbf{p}$} \\
\cline { 3 - 4 } & & Mean & SD & \\
\hline Preterm labor & 29 & 23.56 & 10.69 & \multirow{2}{*}{0.001} \\
Full term labor & 39 & 12.19 & 5.79 & \\
\hline \hline
\end{tabular}

In this table the mean IL-8 level in preterm labor was $23.56 \mathrm{pg} / \mathrm{ml}(\mathrm{SD}=10.69)$, whereas the mean IL-8 level in full term labor was $12.19 \mathrm{pg} / \mathrm{ml}$ $(S D=5.79)$. Based on the result, the mean IL-8 level in preterm labor is higher than full term labor. The mean difference of IL-8 level of these two groups was statistically significant $(\mathrm{p}<0.05)$.

\section{DISCUSSION}

The relationship between preterm labor with intrauterine infection is still unclear. Some of the latest research showed that in the case of intrauterine infection, the process has happened in early pregnancy and has gone undetected for a few months. As an example, Ureaplasma urealyticum infection which was detected in weeks $15-18$ of pregnancy, with most of them going through labor at the $24^{\text {th }}$ week of gestation. Other studies showed that high level of IL- 6 and IL-8 in amniotic fluid at $15-20$ weeks is related with preterm labor at 32-34 weeks. $^{1}$

Previous studies have shown that IL-8 level from cervical biopsy of patients with full term labor in the process of active labor is between 17.2-1954.0 pg/mg. ${ }^{8}$ In full term labor, there is evidence that cytokines played a role in the onset of labor 
through inflammation-like response and there was an increase of IL-8 level in myometrial biopsy. ${ }^{9}$

In a study in amniotic fluid, the IL-8 level was higher in preterm labor than full term labor, and this is related with intrauterine infection. Based on that study, serum IL-8 has the potential to be used as a prognostic factor in preterm labor. ${ }^{10}$

In this research, although there was a significant increase of serum IL-8 level, but the onset of IL-8 increase is still unclear, and we cannot conclude the time since the onset of IL-8 elevation until preterm labor occurs. IL-8 level in amniotic fluid can show the infection process leading to preterm labor, but it requires invasive amniocentesis. Research from Yoneda et al showed that IL-8 from amniotic fluid has a sensitivity of $88 \%$ and specificity af $86.1 \%$ with cut-off value of $22.5 \mathrm{ng} / \mathrm{ml}^{11}$

\section{CONCLUSION}

We concluded from this study that serum IL-8 concentration in women who had preterm labor is significantly higher in comparison to women who had full term labor.

\section{REFERENCES}

1. Goldenberg RL. Intrauterine infection and preterm delivery. New Eng J Med 2000; 342: 1500-7.
2. Turhan ON. Maternal serum interleukin-6 level in preterm labor: prediction of admission to delivery interval. J Perinatal Med 2000; 28: 133-9.

3. Sozmen S. Predictive value of maternal serum and vaginal interleukin-6 level in preterm labor. J Soc Gynecol Investig 2005; 12(4): 1-6.

4. Dubicke A. Preterm and Term Cervical Ripening. Stockholm: Karolinska Institutet; 2009.

5. Cunningham FG. Williams Obstetrics. 23 ${ }^{\text {rd }}$ Ed. New York: The McGraw Hill Comp; 2000.

6. Tornblom SA. Non-infected preterm parturition is related to increased concentration of IL-6, IL- 8 and MCP-1 in human cervix. Reprod Biol Endocrinol 2005; 3(39): 1-10.

7. Dubicke A. Different secretion patterns of matrix metalloproteinases and IL-8 and effect of corticotropin-releasing hormone in preterm and term cervical fibroblasts. Mol Hum Reprod 2008; 14(11): 641-7.

8. Winkler M. Parturition at term: parallel increases in interleukin-8 and proteinase concentration and neutrophil count in the lower uterine segment. J Hum Reprod 1999; 14: 1096-1100.

9. Sehringer B. Formation of proinflammatory cytokines in human term myometrium is stimulated by lipopolysaccharide but not by corticotropin-releasing hormone. J Clin Endocrinol Metabol 2000; 85: 4859-65.

10. Minckwitz GV. Predictive value of serum interleukin- 6 and -8 levels in preterm labor or rupture of the membranes. Acta Obstet Gynecol Scand 2000; 79: 667-72.

11. Yoneda S. Prediction of exact delivery time in patients with preterm labor and intact membranes at admission by amniotic fluid interleukin-8 level and preterm labor index. J Obstet Gynaecol Res 2011; 37: 861-6. 